\title{
PENGARUH MOTIVASI DAN SARANA BELAJAR \\ TERHADAP HASIL BELAJAR GEOGRAFI SISWA KELAS XI DI SMA NEGERI 5 PADANG
}

\author{
Slamet Rianto \\ Program Studi Pendidikan Geografi STKIP PGRI Sumatera Barat \\ slametrianto.com@gmail.com
}

\begin{abstract}
Any educational institution shall have the means, which include furniture, appliances education, media education, books and other learning resources, consumables and other equipment needed to support the learning process on a regular and ongoing. This study aims to get the data and analyze data on: 1) The effect of motivation on learning outcomes geography XI grade students at SMAN 5 Padang. 2) The effect of a learning tool for learning outcomes geography XI grade students at SMAN 5 Padang and 3) Effect of motivation and the means to learn together the learning outcomes geography X1 grade students at SMAN 5 Padang. This research method is descriptive correlational study because it reveals the events and relationships between variables or events are. The population in this research is class student XI.IPS SMA N 5 Padang enrolled academic year 2016/2017 with a sample of the study 84 people. The results of this study show that: 1) There is influence learning motivation towards student learning, where learning motivation variable (27.2\%) of the students' learning outcomes 2) There is no effect of learning tools to the learning outcomes of students of SMAN 5 Padang with a large contribution of 10,3\%, and 3) influences of learning motivation and learning tool together significantly influence student learning outcomes, with a large contribution of $27.4 \%$,
\end{abstract}

Keywords: Motivation and Learning Means Of Learning Outcomes

\section{PENDAHULUAN}

Sekolah merupakan salah satu lembaga pendidikan formal yang menjadi sarana bagi pengembangan potensi dan kemampuan siswa. Di sekolah siswa dapat belajar dengan baik, karena belajar merupakan kegiatan utama siswa di sekolah. Dengan belajar siswa akan mengetahui dan memperoleh kecakapan yang baru serta memperoleh suatu perubahan tingkah laku dan berintegrasi dengan lingkungannya.( Djamarah, 2000: 12).

Pembelajaran merupakan suatu proses perubahan yang sesuai dengan kepribadian bangsa. Belajar merupakan usaha yang dilakukan siswa untuk memperoleh suatu perubahan tingkah laku baru yang secara keseluruhan biasa di dapat dari hasil pengalaman sendiri dan interaksi dengan lingkungannya. Belajar merupakan kegiatan mental yang tidak dapat disaksikan dari luar. Apa yang sedang terjadi dalam diri siswa yang sedang belajar, tidak dapat diketahui secara langsung secara langsung tanpa siswa itu melakukan kegiatan yang menampakkan kemampuannya yang telah diperoleh melalui belajar. Misalnya saling menghormati kebebasan menjalankan ibadah sesuai dengan agama dan kepercayaan masing- 
masing, menyatakan diri dalam sikap tidak memaksakan suatu agama dan kepercayaan kepada orang lain. (Dimyati dan Mujiono, 1994).

Guru memerlukan sesuatu untuk membantu mereka dalam meningkatkan peserta didik yang dibimbingnya agar siswa-siswinya menjadi siswa yang intelektual dan cakap serta berkepribadian yang bagus. Pentingnya sarana pendidikan dinyatakan dalam Peraturan Pemerintah No. 19 tahun 2005 pasal 42 sebagai berikut "setiap satuan pendidikan wajib memiliki sarana yang meliputi perabot, peralatan pendidikan, media pendidikan, buku dan sumber belajar lainnya, bahan habis pakai serta perlengkapan lain yang diperlukan untuk menunjang proses pembelajaran yang teratur dan berkelanjutan"

Mengingat begitu pentingnya keberadaan sarana dalam suatu lembaga pendidikan, untuk itu dibutuhkan upaya-upaya dari setiap lembaga pendidikan dalam menjaga dan memelihara agar sarana selalu dalam kondisi baik dan siap pakai saat dibutuhkan sewaktu-waktu oleh komponen sekolah. Upaya ini menjaga dan memelihara kondisi dari sarana pendidikan adalah tanggung jawab seluruh warga sekolah agar sarana pendidikan berdayaguna sepenuhnya sebagai penunjang pembelajaran, selain itu juga dapat membantu terlaksananya pembelajaran agar dapat berjalan efektif sesuai dengan tujuan yang telah dirumuskan.

Suatu motivasi dapat diekspresikan melalui suatu pernyataan yang menunjukkan bahwa siswa lebih menyukai suatu hal dari pada hal lainnya, dapat pula dimanisfestasikan melalui partisipasi dalam suatu aktivitas. Seseorang yang melakukan aktivitas belajar secara terus menerus tanpa motivasi dari luar dirinya merupakan motivasi instrinsik yang sangat penting dalam aktivitas belajar, dorongan dari luar dirinya merupakan aktivitas ekstrinsik yang diharapkan. Oleh karena itu, motivasi ekstrinsik diperlukan bila motivasi instrinsik tidak ada dalam diri seseorang sebagai subjek belajar. (Djamarah, 2000: 115).

Motivasi mempunyai karakteristik pokok yaitu melakukan kegiatan yang dipilih sendiri dan menyenangkan sehingga dapat membentuk suatu kebiasaan dalam diri seseorang. Motivasi memiliki hubungan dengan segi kognisi. Namun motivasi lebih dekat pada keinginan, sedangkan motivasi adalah sumber untuk mempertahankan keinginan terhadap kegiatan dan menjadikan kegiatan itu sangat menyenangkan. 
Belajar dari pengalaman dan mendapatkan penemuan proses pembelajaran yang sangat baik untuk menjadi siswa aktif dan kreatif sangat ditentukan sekali oleh kemampuan guru dalam mengelola pembelajaran. Karena guru merupakan subjek yang mengajar dan mendidik siswa, tanpa minat dan motivasi, kegiatan belajar tidak akan berjalan dengan lancar dan tidak sesuai dengan apa yang diharapkan.

Hasil belajar siswa adalah merupakan tujuan yang ingin dicapai dari segala usaha yang dilakukan oleh semua aspek yang terlibat dengan pengelolaan proses belajar. Kalau hasil belajar geografi siswa jelek dikatakan pertanda kegagalan dari segala usaha tersebut. Justru itu penulis merasa penting untuk melihat segala sesuatu yang ada hubungannya dengan hasil belajar siswa.

Belajar merupakan proses atau kegiatan yang dijalani secara sadar untuk mendapatkan perubahan baik dalam pengetahuan, sikap ataupun keterampilan (Sadikoen: 1998, dalam Fitria : 2006). Lebih lanjut belajar adalah cara yang dilakukan dalam rangka memperoleh perubahan yaitu didapatkannya kecakapan baru yang dilakukan dengan usaha sendiri (Dimyati dan Mujiono, 1994).

Hasil belajar ini biasanya dapat dinyatakan dalam bentuk angka, atau katakata seperti baik, sedang dan kurang. Sedangkan menurut Sudjana (1991) hasil belajar merupakan perubahan tingkah laku yang mencakup aspek afektif dan psikomotor yang menunjukkan tingkah laku yang ingin dikuasai melalui proses belajar.

Jadi hasil belajar adalah hasil yang diperoleh karena suatu usaha yang meliputi pengetahuan, keterampilan dan sikap yang diperoleh siswa dari proses belajar, perubahan dapat disebut belajar dan belajar merupakan suatu proses yang disengaja, melalui latihan atau pengalaman dalam pengetahuan, kecakapan, tingkah laku dan keterampilan. Dengan demikian terjadinya perubahan tingkah laku dalam diri seseorang dapat disebut sebagai hasil belajar atau prestasi yang diperoleh dari usaha belajar seseorang berupa pengetahuan, keterampilan serta nilai sikap yang diperoleh seseorang setelah mengikuti proses belajar mengajar.

Menurut Mc Donald (dalam Djamarah: 2000) motivasi adalah suatu perubahan energi didalam pribadi seseorang yang ditandai dengan timbulnya efektif dan reaksi untuk mencapai tujuan. Motivasi belajar merupakan jantungnya proses belajar. Dimana motivasi merupakan sesuatu yang tersembunyi di dalam diri seseorang untuk mewujudkan keinginan dan untuk mendorong seseorang agar 
berbuat sesuatu. Motivasi dapat juga dikatakan serangkaian usaha untuk menyediakan kondisi-kondisi tertentu, sehingga seseorang itu mau dan ingin melakukan sesuatu (Slameto, 2010).

Lebih lanjut Jame O Whittaker (dalam Wasty Yamin, 2007) memberi defenisi tentang motivasi adalah kondisi-kondisi atau keadaan makhluk untuk bertingkah mencapai tujuan yang ditimbulkan oleh motivasi tersebut. Selain itu motivasi juga dapat diartikan sebagai "pendorong" suatu usaha yang disadari untuk mempengaruhi tingkah laku seseorang agar ia bergerak hatinya untuk bertindak melakukan sesuatu sehingga mencapai hasil atau tujuan tertentu (Ahmadi: 2007).

Motivasi mengandung tiga komponen pokok, yaitu menggerakkan, mengarahkan dan menopang tingkah laku manusia dalam kegiatan belajar. Jika seseorang mendapat motivasi yang tepat, maka lepaslah tenaga yang luar biasa, sehingga tercapai hasil-hasil yang semua tidak terduga (Slameto: 2010). Selain itu juga dalam pembelajaran harus didukung oleh beberapa unsur yang berkaitan dengan motivasi belajar. Adapun belajar itu mempunyai cita-cita, kemampuan kondisi lingkungan belajar, kondisi-kondisi dinamis belajar dan kemampuan guru dalam membelajarkan siswa. Seorang guru terpaksa melibatkan proses berbagai motif kelakuan seseorang yang diukur dari segi perubahan keinginan keperluan dan maklumatnya (Djamarah, 2000)

Lebih lanjut Yamin (2007) mengemukakan ciri-ciri motivasi belajar yang ada pada diri seseorang siswa adalah : tekun dalam menghadapi hasil belajar terus menerus, tidak putus asa, tidak cepat puas terhadap hasil belajar, tidak tergantung terhadap orang lain, tidak cepat bosan dengan tugas rutin, menunjukkan minat yang besar terhadap bermacam-macam masalah belajar, dapat mempertahankan pendapat dan senang mencari penyelesaian atau memecahkan masalah. Dengan demikian motivasi belajar memegang peranan penting dalam memberikan gairah, semangat dan rasa senang dalam belajar sehingga siswa mempunyai kemampuan untuk melaksanakan kegiatan belajar.

Sarana berarti alat langsung untuk mencapai tujuan pendidikan, seperti ruang, buku, perpustakaan, laboratorium dan sebagainya. Dengan demikiandapat dikatakan sarana adalah semua komponen secara langsung menunjang jalannya proses pendidikan untuk mencapai tujuan dalam pendidikan itu. Menurut keputusa perdana menteri P dan K No 079/1975, sarana terdiri dari tiga kelompok besar yaitu: 
a. Bangunan dan perabot sekolah

b. Alat pelajaran yang terdiri dari pembukuan, alat-alat peraga dan laboratorium

c. Media pendidikan yang dapat di kelompokkan menjadi audiovisual yang menggunakan alat penampi

Tujuan sarana pendidikan adalah untuk menghindari terjadinya kesalahan dan kegagalan yang tidak di inginkan dan untuk meningkatkan efektifitas efesiensi dalam pelaksanaannya. Perencanaan pengadaan sarana pendidikan dilakukan berdasarkan analisis kebutuhan dan penentuan skala prioritas kegiatan untuk dilaksanakan yang di sesuaikan dengan tersedianya dana dan tingkat kepentingan.

Manfaat perencanaan sarana pendidikan, manfaat perencanaan yaitu dapat membantu dalam menentukan tujuan, meletakkan dasar-dasar dan menetapkan langkah-langkah, menghilangkan ketidakpastian, dapat di jadikan sebagai suatu pedoman atau dasar untuk melakukan pengawasan, pengendalian dan bahkan juga penilaian agar nantinya kegiatan berjalan dengan efektif dan efesien.

\section{Hipotesis Penelitian}

Berdasarkan rumusan masalah dan tujuan penelitian yang dikemukakan diatas maka hipotesis penelitian ini adalah:

1. Terdapat pengaruh yang signifikan antara motivasi terhadap hasil belajar geografi kelas XI di SMA Negeri 5 Padang.

2. Terdapat pengaruh yang signifikan sarana belajar dengan hasil belajar geografi kelas XI di SMA Negeri 5 Padang .

3. Terdapat pengaruh yang signifikan motivasi dan sarana belajar secara bersamasama dengan hasil belajar geografi kelas XI di SMA Negeri 5 Padang.

\section{PEMBAHASAN}

Penelitian ini membahas 3 variabel yang terdiri dari dua variabel bebas yaitu Motivasi belajar $\left(\mathrm{X}_{1}\right)$, Sarana belajar $\left(\mathrm{X}_{2}\right)$ dan satu variabel terikat yaitu hasil belajar siswa (Y).

\section{Distribusi Data Hasil belajar siswa (Y)}

Berdasarkan data yang diperoleh di lapangan tentang hasil belajar siswa motivasi dalam pendidikan anak didapat skor terendah 32,0 sampai tertinggi 100,0 dan nilai rata-rata sebesar 66,785 dan standar deviasi sebesar 15,480. Untuk lebih jelasnya data tersebut disajikan dalam tabel dibawah ini. 
Tabel 1 : Distribusi Data Hasil Belajar Siswa Kelas XI IPS SMAN 5 Padang

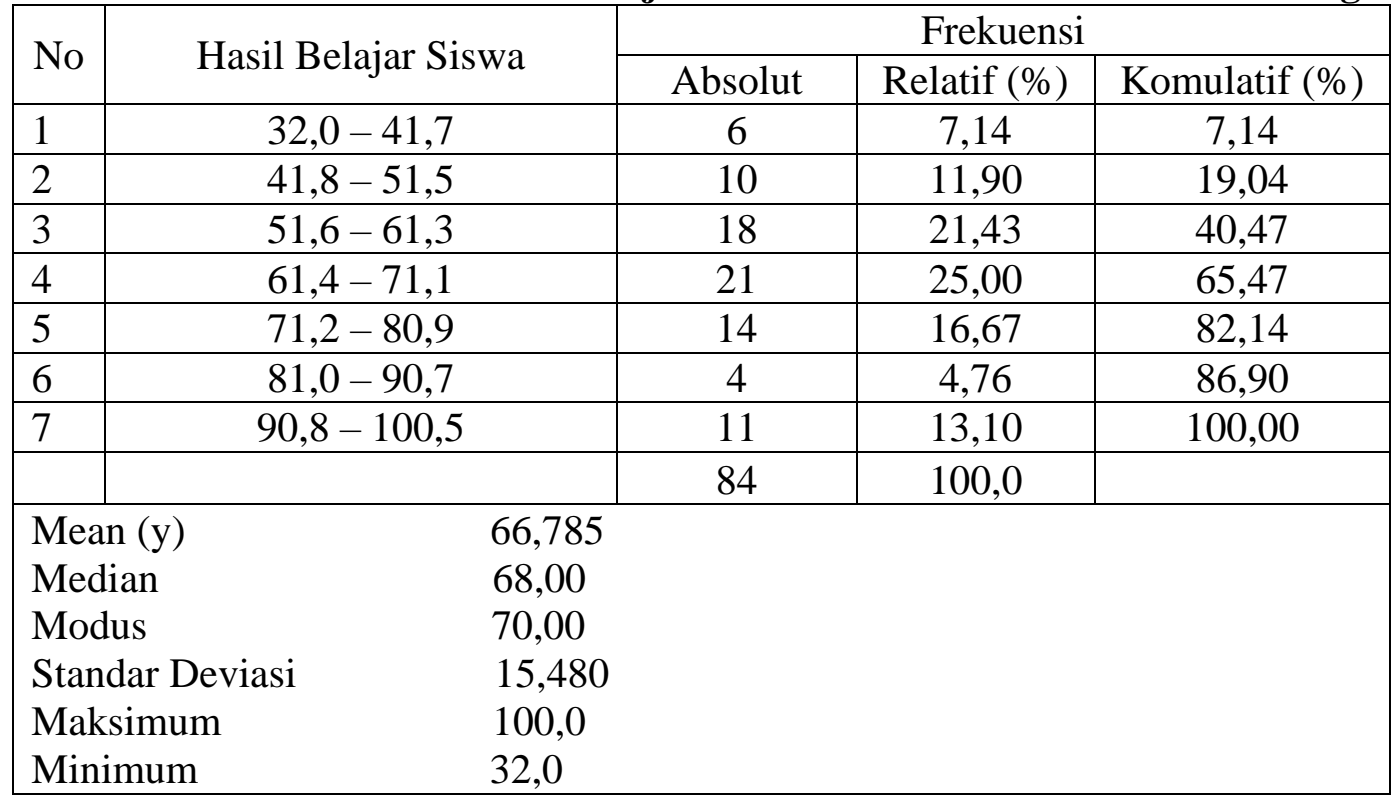

\section{Sumber : Pengolahan Data Primer, 2016}

Distribusi data di atas menunjukan bahwa $25,0 \%$ dari responden memiliki skor rata-rata, 40,47\% responden memiliki skor dibawah rata-rata dan $34,53 \%$ responden memiliki skor di atas rata-rata. Dapat diambil kesimpulan bahwa hasil belajar siswa termasuk rendah atau di bawah rata-rata. Distribusi frekuensi data di atas disajikan dalam histogram frekuensi hasil belajar siswa sebagai berikut :

Gambar 1 Histogram Hasil Belajar Siswa

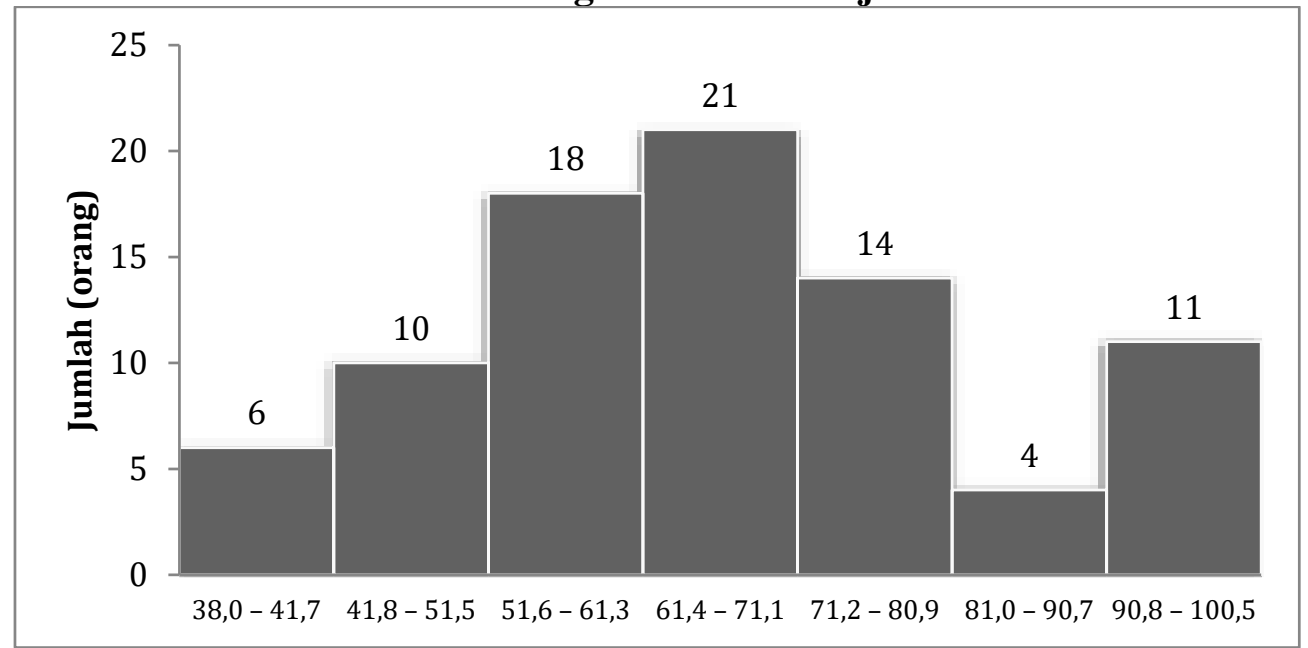

Sumber: Pengolahan Data Primer, 2016

\section{Distribusi Data Motivasi belajar $\left(\mathrm{X}_{1}\right)$}

Berdasarkan data yang diperoleh di lapangan tentang Motivasi belajar didapat rentangan skor terendah 31,0 sampai skor tertinggi 54,0 dan nilai rata-rata sebesar 42,011 dan standar deviasi sebesar 4,49. Untuk lebih jelasnya data tersebut disajikan dalam tabel dibawah ini.

Tabel 2 : Distribusi Data Motivasi Belajar

\begin{tabular}{|l|l|l|l|l|}
\hline \multirow{2}{*}{ No } & \multirow{2}{*}{ Motivasi Belajar } & \multicolumn{3}{|c|}{ Frekuensi } \\
\cline { 3 - 5 } & & Absolut & Relatif (\%) & Komulatif (\%) \\
\hline
\end{tabular}




\begin{tabular}{|c|c|c|c|c|}
\hline 1 & $31,0-34,3$ & 4 & 4,76 & 4,76 \\
\hline 2 & $34,4-37,7$ & 8 & 9,52 & 14,28 \\
\hline 3 & $37,8-41,1$ & 28 & 33,33 & 47,62 \\
\hline 4 & $41,2-44,5$ & 22 & 26,19 & 73,81 \\
\hline 5 & $44,6-47,9$ & 12 & 14,29 & 88,09 \\
\hline 6 & $48,0-51,3$ & 8 & 9,52 & 97,62 \\
\hline \multirow[t]{2}{*}{7} & $51,4-54,7$ & 2 & 2,38 & 100,00 \\
\hline & & 84 & 100,0 & \\
\hline \multicolumn{2}{|c|}{ Mean (X1) } & \multicolumn{3}{|c|}{42,011} \\
\hline \multicolumn{2}{|c|}{ Median } & \multicolumn{3}{|c|}{42,00} \\
\hline \multicolumn{2}{|c|}{ Modus } & \multicolumn{3}{|c|}{42,00} \\
\hline \multicolumn{2}{|c|}{ Standar Deviasi } & \multicolumn{3}{|c|}{4,49} \\
\hline \multicolumn{2}{|c|}{ Maksimum } & \multicolumn{3}{|c|}{54.00} \\
\hline \multicolumn{2}{|c|}{ Minimum } & \multicolumn{3}{|c|}{31,00} \\
\hline
\end{tabular}

\section{Sumber : Pengolahan Data Primer, 2016}

Distribusi data di atas menunjukan bahwa 26,19\% dari responden memiliki skor rata-rata, $47,62 \%$ responden memiliki skor dibawah rata-rata dan $26,19 \%$ responden memiliki skor di atas rata-rata. Dapat diambil kesimpulan bahwa hasil motivasi belajar siswa berada dalam kategori sedang. Distribusi frekuensi data di atas disajikan dalam histogram frekuensi hasil belajar siswa sebagai berikut :

Gambar 2 Histogram Motivasi belajar Siswa

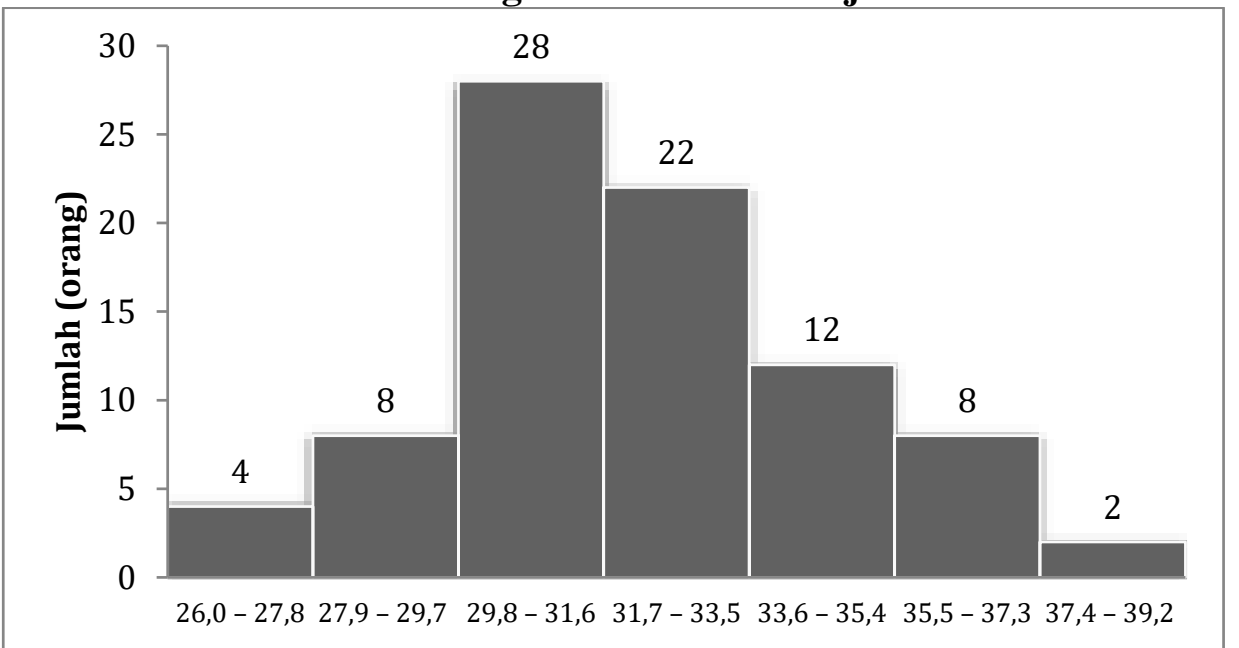

\section{Distribusi Data Sarana belajar (X2)}

Berdasarkan data yang diperoleh di lapangan tentang motivasi dalam pendidikan anak didapat skor terendah 23,0 sampai tertinggi 53,0 dan nilai rata-rata sebesar 37,73 dan standar deviasi sebesar 6,16. Untuk lebih jelasnya data tersebut disajikan dalam tabel dibawah ini.

Tabel 3 : Distribusi Data Sarana belajar

\begin{tabular}{|l|l|l|l|l|}
\hline \multirow{2}{*}{ No } & Sarana belajar & \multicolumn{3}{|c|}{ Frekuensi } \\
\cline { 3 - 4 } & & Absolut & Relatif (\%) & Komulatif (\%) \\
\hline
\end{tabular}




\begin{tabular}{|c|c|c|c|c|}
\hline 1 & $23,0-27,3$ & 2 & 2,38 & 2,38 \\
\hline 2 & $27,4-31,7$ & 15 & 17,86 & 20,24 \\
\hline 3 & $31,8-36,1$ & 18 & 21,43 & 41,67 \\
\hline 4 & $36,2-40,5$ & 23 & 27,38 & 69,05 \\
\hline 5 & $40,6-44,9$ & 15 & 17,86 & 86,90 \\
\hline 6 & $45,0-49,3$ & 7 & 8,33 & 95,24 \\
\hline \multirow[t]{2}{*}{7} & $49,4-53,7$ & 4 & 4,76 & 100,00 \\
\hline & & 84 & 100,0 & \\
\hline \multicolumn{2}{|c|}{ Mean (X3) } & \multicolumn{3}{|c|}{37,738} \\
\hline \multicolumn{2}{|c|}{ Median } & \multicolumn{3}{|c|}{37,00} \\
\hline \multicolumn{2}{|c|}{ Modus } & \multicolumn{3}{|c|}{36,00} \\
\hline \multicolumn{2}{|c|}{ Standar Deviasi } & \multicolumn{3}{|c|}{6,16} \\
\hline \multicolumn{2}{|c|}{ Maksimum } & \multicolumn{3}{|c|}{53,0} \\
\hline \multicolumn{2}{|c|}{ Minimum } & \multicolumn{3}{|c|}{23,0} \\
\hline
\end{tabular}

\section{Sumber : Pengolahan Data Primer, 2016}

Distribusi data di atas menunjukan bahwa $27,38 \%$ dari responden memiliki skor rata-rata, 41,67\% responden memiliki skor dibawah rata-rata dan 30,85\% responden memiliki skor di atas rata-rata. Dapat diambil kesimpulan bahwa sarana belajar di SMAN 5 Padang termasuk kategori tinggi. Distribusi frekuensi data di atas disajikan dalam histogram frekuensi sarana belajar sebagai berikut :

Gambar 3 Histogram Sarana belajar

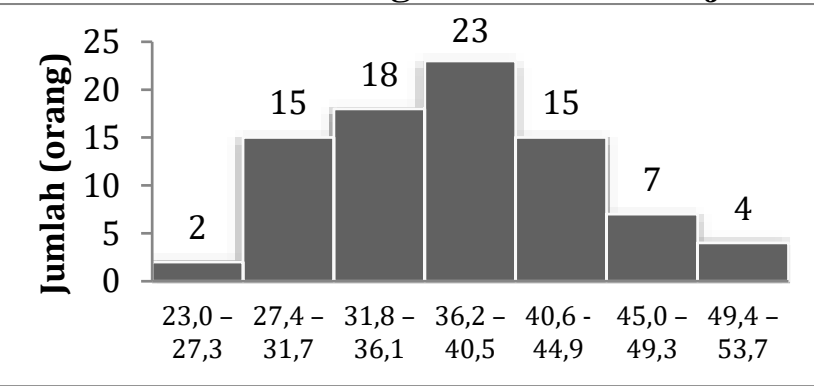

Sumber: Pengolahan Data Primer, 2016

Jika angka-angka statistik dari variabel tersebut disajikan secara keseluruhan maka diperoleh tabel rekapitulasi seperti di bawah ini :

Tabel 4 : Rekapitulasi Angka Statistik Data Penelitian Responden di SMA Negeri 5 Padang

\begin{tabular}{|l|l|l|l|l|}
\hline No & Variabel & Rentangan Skor & Rata-rata & $\begin{array}{l}\text { Simpangan } \\
\text { Baku }\end{array}$ \\
\hline 1 & X1 (Motivasi belajar) & $31,0-54,0$ & 42,011 & 4,49 \\
\hline 2 & X2 (Sarana belajar) & $23,0-53,0$ & 37,738 & 6,160 \\
\hline 3 & Y (Hasil belajar siswa) & $32,0-100,0$ & 66,785 & 15,480 \\
\hline
\end{tabular}

Sumber : Pengolahan Data Primer, 2016

\section{Pengujian Hipotesis}

1. Pengaruh Motivasi Belajar Terhadap Hasil belajar Siswa SMAN 5 Padang 
Hasil analisis pengaruh motivasi belajar dengan anak SMAN 5 Padang diperoleh seperti tabel berikut ini:

Tabel 7 : Analisis Regresi Sederhana Antara Variabel Motivasi belajar Dengan Hasil belajar siswa SMAN 5 Padang

\begin{tabular}{|c|c|c|c|c|c|c|c|}
\hline \multirow{3}{*}{ Variabel } & \multirow{3}{*}{$\begin{array}{l}\text { Koefisien } \\
\text { Regresi }\end{array}$} & \multirow{3}{*}{$\begin{array}{l}\text { Standar } \\
\text { Eror }\end{array}$} & \multicolumn{3}{|c|}{$\mathrm{T}$} & \multicolumn{2}{|c|}{$\begin{array}{l}\text { Pengujian } \\
\text { Hipotesis }\end{array}$} \\
\hline & & & \multirow[b]{2}{*}{ Hitung } & \multicolumn{2}{|c|}{ Tabel } & \multirow[b]{2}{*}{ Ho } & \multirow[b]{2}{*}{ H1 } \\
\hline & & & & $\begin{array}{c}\alpha \\
=0,05\end{array}$ & $\begin{aligned} & \alpha \\
= & 0,01\end{aligned}$ & & \\
\hline $\mathrm{X}_{1}$ & 0,853 & 0,091 & 2,560 & 1,663 & 1,989 & & $\sqrt{ }$ \\
\hline \multicolumn{8}{|c|}{ Constanta $=29,805$} \\
\hline \multirow{2}{*}{\multicolumn{2}{|c|}{$\begin{array}{l}\text { Standar Error of East } \\
\text { r square }\end{array}$}} & \multicolumn{6}{|c|}{$=13,633$} \\
\hline & & \multicolumn{6}{|l|}{$=0,074$} \\
\hline \multicolumn{2}{|l|}{ r.square } & \multicolumn{6}{|l|}{$=0,272$} \\
\hline
\end{tabular}

\section{Sumber : Pengolahan Data Primer, 2016}

Berdasarkan analisis regresi linier sederhana dari data penelitian diperoleh koefisien regresi 0,853 dan konstanta 29,805. Dengan demikian bentuk hubungan antara kedua variabel dapat disajikan dalam persamaan regresi $\mathrm{Y}=0,853+$ $29,805 X_{1}$. Hasil pengujian melalui uji t diperoleh $t$ hitung sebesar 2,560, sedangkan $t_{\text {tabel }}$ pada taraf kepercayaan $\alpha=0,01$ sebesar 1,66, kekuatan hubungan sebesar 0,272 antara variabel motivasi belajar dengan hasil belajar anak SMAN 5 Padang, pengaruh motivasi terhadap hasil belajar sebesar 27,2\%. Dengan demikian terbukti bahwa koefisien tersebut berarti atau hipotesis yang diajukan diterima. Selanjutnya di uji menggunakan uji $\mathrm{F}$ adapun hasilnya dapat dilihat pada tabel berikut ini :

Tabel 8 : Analisis Varians Variabel Motivasi belajar Dengan Hasil belajar siswa

\begin{tabular}{|l|c|c|c|c|c|c|}
\hline \multirow{2}{*}{ Source } & $\begin{array}{c}\text { Sum Of } \\
\text { Square }\end{array}$ & DF & \multirow{2}{*}{$\begin{array}{c}\text { Mean } \\
\text { Square }\end{array}$} & \multirow{2}{*}{ Fo } & \multicolumn{2}{c|}{ F tabel } \\
\cline { 6 - 8 } & & & & $\alpha=0,05$ & $\alpha=0,01$ \\
\hline Regression & 1218,061 & 1 & 1218,061 & 6,553 & 3,95 & 6,90 \\
Residual & 15241,498 & 82 & 185,875 & & & \\
\hline Total & 16459,560 & 83 & & & & \\
\hline
\end{tabular}

\section{Sumber : Pengolahan Data Primer, 2016}

Berdasarkan Tabel IV.9 di atas diperoleh harga F hitung sebesar 6,553 harga ini lebih besar dibandingkan dengan harga $F$ tabel dengan DF pembilang 1 dan penyebut 82 pada taraf kepercayaan $\alpha=0,05$ sebesar 3,99 dan $\alpha=0,01$ sebesar 6,90, dengan membandingkan $\mathrm{F}$ hitung dengan $\mathrm{F}$ tabel tersebut diketahui bahwa koefisien regresi signifikan karena $\mathrm{F}$ hitung lebih besar dari $\mathrm{F}_{\text {tabel. }}$

Tabel 9 : Analisis Keberartian Koefisien Korelasional $\mathbf{r}_{\mathrm{xy}}$

\begin{tabular}{|c|l|l|}
\hline \multirow{2}{*}{ rx 1y } & \multicolumn{2}{|c|}{$r$ tabel pada taraf signifikan } \\
\cline { 2 - 3 } & $\alpha 0,05$ & $\alpha, 01$ \\
\hline 0,272 & 0,206 & 0,244 \\
\hline
\end{tabular}

\section{Sumber : Pengolahan Data Primer,2016}

Hasil perhitungan koefisien korelasi antara variabel motivasi belajar dengan hasil belajar siswa $r_{x y}$ sebesar 0,272. Hasil pengujian menunjukan pengaruh motivasi belajar terhadap hasil belajar secara signifikan dan positif pada anak SMAN 5 Padang melalui model regresi $\mathrm{Y}=0,853+29,805 \mathrm{X}_{1}$. 
Apabila pengontrolan dilakukan terhadap variabel bebas lainnya (sarana belajar) maka diperoleh koefisien korelasi partial antara motivasi belajar $\left(\mathrm{X}_{1}\right)$ dengan hasil belajar siswa (Y) sebesar 0,272. Dalam hal ini menerima hipotesis nol yang menyatakan motivasi belajar berpengaruh terhadap hasil belajar siswa SMAN 5 Padang Ini berarti motivasi belajar merupakan faktor yang cukup penting dalam menentukan hasil belajar siswa SMAN 5 Padang.

\section{Pengaruh Sarana Belajar terhadap Hasil belajar Siswa SMAN 5 Padang}

Hasil analisis pengaruh sarana belajar terhadap hasil belajar siswa SMAN 5 Padang seperti tabel berikut ini:

Tabel 10 : Analisis Regresi Sederhana Antara Variabel Sarana belajar Terhadap Hasil belajar Siswa SMAN 5 Padang

\begin{tabular}{|c|c|c|c|c|c|c|c|}
\hline \multirow{3}{*}{ Variabel } & \multirow{3}{*}{$\begin{array}{c}\text { Koefisien } \\
\text { Regresi }\end{array}$} & \multirow{3}{*}{$\begin{array}{c}\text { Standar } \\
\text { Error }\end{array}$} & \multicolumn{3}{|c|}{$\mathrm{T}$} & \multicolumn{2}{|c|}{$\begin{array}{c}\text { Pengujian } \\
\text { Hipotesis }\end{array}$} \\
\hline & & & \multirow[b]{2}{*}{ Hitung } & \multicolumn{2}{|c|}{ Tabel } & \multirow[b]{2}{*}{ Ho } & \multirow[b]{2}{*}{ H1 } \\
\hline & & & & $\begin{array}{l}\alpha \\
=0,05\end{array}$ & $\begin{array}{l}\alpha \\
=0,01\end{array}$ & & \\
\hline $\mathrm{X}_{2}$ & 0,236 & 0,251 & 0,939 & 1,663 & 1,989 & $\sqrt{ }$ & \\
\hline \multicolumn{2}{|c|}{$\begin{array}{l}\text { Constanta } \\
\text { Standar Error of East } \\
\text { r.square }\end{array}$} & $\begin{array}{l}=56,73 \\
=14,09 \\
=0,011 \\
=0,103\end{array}$ & & & & & \\
\hline
\end{tabular}

Sumber : Pengolahan Data Primer, 2016

Berdasarkan analisis regresi linier sederhana dari data penelitian diperoleh koefisien regresi 0,236 dan konstanta 56,732. Dengan demikian pengaruh variabel sarana belajar terhadap hasil belajar dapat disajikan dalam persamaan regresi $\mathrm{Y}=$ $0,236+56,732 X_{2}$, hasil pengujian melalui uji $\mathrm{t}$ diperoleh $\mathrm{t}$ hitung sebesar 0,939 , sedangkan $\mathrm{t}$ tabel pada taraf kepercayaan $\alpha=0,01$ sebesar 1,898 dan $\alpha=0,05$ sebesar 1,663 , besarnya pengaruh sarana belajar sebesar 0,103 terhadap hasil belajar siswa SMAN 5 Padang. Sarana belajar memberi pengaruh terhadap hasil belajar memberi kontribusi sebesar 10,3\%. Dengan demikian tidak terbukti bahwa sarana belajar berpengaruh terhadap hasil belajar atau hipotesis yang diajukan ditolak. Selanjutnya di uji menggunakan uji $\mathrm{F}$ adapun hasilnya dapat dilihat pada tabel berikut ini :

Tabel 11 : Analisis Varians Variabel Sarana belajar terhadap Hasil Belajar SMAN 5 Padang

\begin{tabular}{|c|c|c|c|c|c|c|}
\hline \multirow{2}{*}{ Source } & \multirow{2}{*}{$\begin{array}{l}\text { Sum Of } \\
\text { Square }\end{array}$} & \multirow{2}{*}{$\mathrm{DF}$} & \multirow{2}{*}{$\begin{array}{l}\text { Mean } \\
\text { Square }\end{array}$} & \multirow{2}{*}{ Fo } & \multicolumn{2}{|c|}{ F tabel } \\
\hline & & & & & $\alpha 0,05$ & $\alpha 0,01$ \\
\hline $\begin{array}{l}\text { Regression } \\
\text { Residual }\end{array}$ & $\begin{array}{l}175,184 \\
16284,375\end{array}$ & $\begin{array}{c}1 \\
82\end{array}$ & $\begin{array}{l}175,184 \\
198,590\end{array}$ & 0,882 & 3,95 & 6,90 \\
\hline Total & 16459,56 & & & & & \\
\hline
\end{tabular}




\section{Sumber : Pengolahan Data Primer, 2016}

Berdasarkan Tabel IV.12 di atas diperoleh harga $F$ hitung sebesar 0,882, harga ini lebih kecil dibandingkan dengan harga $F$ tabel dengan DF pembilang 1 dan penyebut 82 pada taraf kepercayaan $\alpha=0,05$ sebesar 3,95 dan $\alpha=0,01$ sebesar 6,90 dengan membandingkan $\mathrm{F}$ hitung dengan $\mathrm{F}$ tabel tersebut diketahui bahwa koefisien regresi tidak signifikan karena $\mathrm{F}$ hitung lebih kecil dari $\mathrm{F}$ tabel.

Tabel 12 : Analisis Keberartian Koefisien Korelasional rxy

\begin{tabular}{|l|l|l|}
\hline \multirow{2}{*}{ xy } & r tabel pada taraf signifikan \\
\cline { 2 - 3 } & $\alpha 0,05$ & $\alpha 0,01$ \\
\hline 0,103 & 0,206 & 0,244 \\
\hline
\end{tabular}

\section{Sumber : Pengolahan Data Primer,2016}

Hasil perhitungan koefisien korelasi antara variabel sarana belajar dengan

Hasil belajar siswa rxy sebesar 0,103. Hasil pengujian menunjukan sarana belajar tidak berpengaruh terhadap hasil belajar, melalui model regresi $\mathrm{Y}=0,236+$ $56,732 \mathrm{X}_{2}$,

Apabila pengontrolan dilakukan terhadap variabel bebas lainnya (motivasi belajar) maka diperoleh koefisien korelasi partial antara motivasi belajar $\left(\mathrm{X}_{1}\right)$ dengan hasil belajar siswa (Y) sebesar 0,175. Dalam hal dan sekaligus menolak hipotesis nol yang menyatakan sarana belajar berpengaruh terhadap hasil belajar siswa SMAN 5 Padang. Ini berarti sarana belajar bukan faktor yang penting dalam menentukan hasil belajar.

\section{Pengaruh Antara Motivasi belajar dan Sarana belajar terhadap Hasil belajar siswa SMAN 5 Padang}

Hipotesis ketiga dalam penelitian ini adalah motivasi belajar dan sarana belajar secara besama-sama berpengaruh terhadap hasil belajar siswa SMAN 5 Padang untuk menguji hipotesis ketiga penelitian ini dilakukan melalui analisis regresi ganda (multiple regression) dan uji F. Dari analisis regresi lineir berganda terhadap data penelitian, diperoleh hasil seperti terdapat pada tabel berikut :

Tabel 13 : Analisis Regresi Ganda Antara Variabel Motivasi belajar dan Sarana belajar Terhadap Hasil belajar siswa SMAN 5 Padang

\begin{tabular}{|c|c|c|c|c|c|c|}
\hline \multirow{3}{*}{ Variabel } & \multirow{3}{*}{$\begin{array}{c}\text { Koefisien } \\
\text { Regresi }\end{array}$} & \multirow{3}{*}{$\begin{array}{c}\text { Standar } \\
\text { Eror }\end{array}$} & \multicolumn{3}{|c|}{$\mathrm{T}$} & \multirow[b]{3}{*}{ Partial } \\
\hline & & & \multirow[b]{2}{*}{ Hitung } & \multicolumn{2}{|c|}{ Tabel } & \\
\hline & & & & $\begin{aligned} & \alpha \\
= & 0,05\end{aligned}$ & $\begin{array}{c} \\
\alpha \\
=0,01\end{array}$ & \\
\hline $\mathrm{X}_{1}$ & 0,825 & 0,347 & 2,376 & 1,663 & 1,989 & 0,272 \\
\hline $\mathrm{X}_{2}$ & 0,078 & 0,253 & 0,309 & & & 0,020 \\
\hline \multicolumn{7}{|c|}{ Constanta $\quad=28,036$} \\
\hline \multicolumn{7}{|c|}{ Standar Error of East $=13,709$} \\
\hline \multicolumn{2}{|c|}{ Adjusted R Squared } & \multicolumn{5}{|c|}{$=0,052$} \\
\hline \multicolumn{2}{|l|}{ r.square } & \multicolumn{5}{|l|}{$=0,075$} \\
\hline \multicolumn{2}{|l|}{$\mathrm{r}$} & \multicolumn{5}{|c|}{$=0,274$} \\
\hline
\end{tabular}

Sumber : Pengolahan Data Primer, 2016

Dari analisis di atas bentuk hubungan ketiga variabel dapat disajikan suatu persaman $\mathrm{Y}=28,036+0,825 \mathrm{X}_{1}+0,078 \mathrm{X}_{2}$. 
Persamaan regresi berganda di atas diperoleh harga determininasi ganda atau R Squared sebesar 0,052. Kontribusi yang diberikan variabel motivasi belajar dan sarana belajar terhadap hasil belajar siswa SMAN 5 Padang 27,4\% variabel hasil belajar siswa SMAN 5 Padang (Y) ditentukan oleh variabel Motivasi belajar (X1) dan Sarana belajar (X2) secara bersama-sama. Apabila pengontrol dilakukan terhadap variabel bebas motivasi belajar (X1), diperoleh koefisien korelasi partial terhadap hasil belajar siswa sebesar 0,272. Untuk mengetahui derajat keberartian regresi ganda tersebut selanjutnya di uji $\mathrm{F}$ dan hasilnya terlihat pada tabel di bawah ini :

Tabel 14 : Daftar Analisis Varians Variabel Motivasi belajar dan Sarana belajar Terhadap Hasil belajar siswa SMAN 5 Padang

\begin{tabular}{|l|l|c|c|c|c|c|}
\hline \multirow{2}{*}{ Source } & \multirow{2}{*}{$\begin{array}{c}\text { Sum Of } \\
\text { Square }\end{array}$} & DF & \multirow{2}{*}{$\begin{array}{c}\text { Mean } \\
\text { Square }\end{array}$} & Fo & \multicolumn{2}{|c|}{ F tabel } \\
\cline { 6 - 8 } & & & & & $\alpha 0,05$ & $\alpha 0,01$ \\
\hline Regression & 1235,983 & 2 & 617,991 & 3,288 & 3,109 & 5,48 \\
Residual & 15223,577 & 81 & 187,945 & & & \\
\hline Total & 16459,56 & 83 & & & & \\
\hline
\end{tabular}

Sumber : Pengolahan Data Primer, 2016

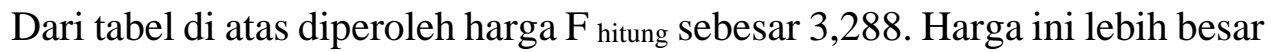
dibandingkan harga $\mathrm{F}$ tabel dengan dk pembilang 2 dan $\mathrm{dk}$ penyebut 81, pada taraf kepercayaan $\alpha=0,05$ yaitu 3,109 tetapi lebih kecil dari $\alpha=0,01$ yaitu 5,48. Dengan membandingkan harga $\mathrm{F}$ hitung dengan $\mathrm{F}$ tabel tersebut diketahui bahwa koefisien regresi cukup signifikan.

Tabel 15 : Analisis Keberartian Koefisien Korelasi berganda rxy

\begin{tabular}{|c|c|c|}
\hline \multirow{2}{*}{$\mathrm{r} x y$} & \multicolumn{2}{|c|}{$\mathrm{r}$ tabel pada taraf signifikan } \\
\cline { 2 - 3 } & $\alpha 0,05$ & $\alpha 0,01$ \\
\hline 0,274 & 0,182 & 0,217 \\
\hline
\end{tabular}

Sumber : Pengolahan Data Primer, 2016

Catatan : signifikan karena rxy yang diperoleh lebih besar $F$ tabel pada $a=0.05$ dan $\mathrm{a}=0,01$.

Hasil analisis di atas dapat disimpulkan bahwa koefisien korelasi ganda (R) adalah 0,274 , ternyata signifikan dan sekaligus menerima hipotesis kerja yang menyatakan terdapat pengaruh motivasi belajar dan sarana belajar secara bersamasama terhadap hasil belajar siswa SMAN 5 Padang

\section{KESIMPULAN}

Berdasarkan temuan dan pembahasan hasil penelitian, maka kesimpulan hasil penelitian ini dapat dirumuskan sebagai berikut :

1. Terdapat pengaruh motivasi belajar terhadap hasil belajar siswa SMAN 5

Padang, dimana variabel motivasi belajar $(27,2 \%)$ terhadap hasil belajar siswa SMAN 5 Padang.

2. Tidak terdapat pengaruh sarana belajar terhadap hasil belajar siswa SMAN 5 Padang dengan besar kontribusi 10,3\%.

3. Terdapat pengaruh motivasi belajar dan sarana belajar secara bersama-sama signifikan dan positif terhadap hasil belajar siswa SMAN 5 Padang dengan besar kontribusi $27,4 \%$. 


\section{DAFTAR PUSTAKA}

Ahmadi, Abu. 2007. Psikologi Sosial. Jakarta: Rineka Cipta

Arikunto, Suhasimi 2006. Prosedur Penelitian Suatu Pendekatan Praktik. Jakarta: Rineka Cipta

Buston, W.H. 2003. Psikologi Pendidikan. Jakarta: PT Rineka cipta

Crow, D.L., dan Crow, A. 1989. Psikologi Pendidikan. Yogyakarta : Nur Cahaya.

Dalyono, M. 1997. Psikologi Pendidikan. Jakarta : Rineka Cipta.

Djamarah, Syaiful Bahri. 2002. Psikologi Belajar. Jakarta: Rineka Cipta

Dimyati dan Mujiono. 1994. Belajar dan faktor-faktor yang mempengaruhi. Jakarta: Rineka Cipta

Djaali. 2007. Psikologi Pendidikan. Jakarta : Rajawali Pers.

Hamalik, Oemar. 1992. Psikologi Belajar dan Mengajar. Bandung : Sinar Baru Algesindo

Hudoyono. 2006. Motivasi belajar dan intruksional Jakarta: Rajawali pers

Purwanto, M. Ngalin. 2002. Psikologi Pendidikan. Bandung : PT Remaja Rosdakarya.

Slameto. 2010. Belajar dan Faktor-Faktor yang Mempengaruhinya. Jakarta: Rineka Cipta

Sudjana. 1991. Psikologi Pendidikan. Jakarta: Rineka Cipta.

Sudjana, Nana dan Ibrahim. 2007. Penelitian dan Penilaian Pendidikan. Bandung: Sinar Baru Algesindo

Ucer, Lilis. 1993. Motivasi Belajar Dan Intruksional. Jakarta: Rajawali Pers

Yamin, Martinis. 2007. Profesionalisasi Guru dan Implementasi KTSP. Jakarta: Gaung Persada Press 